\title{
PENGARUH PERSEPSI KEMIRIPAN, KONSEP MEREK DAN PESAN IKLAN TERHADAP RESPON KONSUMEN DALAM MENGEVALUASI PERLUASAN MEREK
}

\author{
Arini Ekaputri Junaedi ${ }^{\mathrm{a}}$ \\ Badri Munir Sukoco ${ }^{\text {b }}$ \\ ${ }^{a}$ Sekolah Pascasarjana Universitas Airlangga ${ }^{b}$ Fakultas Ekonomi dan Bisnis Universitas Airlangga \\ Email: arini.eka.junaedi@gmail.com $; \underline{\text { badri@feb.unair.ac.id }}$
}

ARTICLE HISTORY

Received:

9 June 2017

Revised

6 July 2017

Accepted:

22 July 2017

Online available:

9 November 2017

Keywords:

Brand Expansion, Similarity of Product Categories, Brand Concept, Function of Attitude, Advertising Message

Kata Kunci:

Perluasan Merek, Kemiripan Kategori

Produk, Konsep

Merek, Fungsi Sikap, Pesan Iklan

\section{ABSTRACT}

Introduction: This study aims to determine the effect of product category similarity when associated with brand concepts and advertising messages on consumer responses in evaluating brand expansion. To get the research objective, two studies were conducted sequentially.

Methods: The first study used experiments conducted on the similarity category of the product and the brand concept. The second study uses experiments conducted on product similarity categories and advertising messages. Experiments in both studies were carried out using the between-subject method with 240 undergraduate students at the Faculty of Economics and Business, Airlangga University (120 students for each study) as participants.

Results: The experimental results from the first study show that the prestigious brand concept has a better ability (compared to the functional brand concept) to carry out brand expansion both in product categories that are similar or not similar to the original brand. The experimental results from the second stage study show that a prestigious brand will be able to increase its ability to expand the brand if the product is advertised with a social-adjustive message for similar product categories, and for dissimilar product categories it will be more effective if advertised with a value-expressive message.

Conclusion and suggestion: Companies that do brand extensions to different product categories are advised to use ads with value-expressive messages to make them more effective. 


\begin{abstract}
Abstrak
Penelitian ini bertujuan untuk mengetahui pengaruh kemiripan kategori produk jika dikaitkan dengan konsep merek dan pesan iklan terhadap respon konsumen dalam mengevaluasi perluasan merek. Untuk mendapatkan tujuan penelitian, dilakukan dua studi secara sekuensial. Studi pertama menggunakan eksperimen yang dilakukan terhadap kategori kemiripan produk dan konsep merek. Studi kedua menggunakan eksperimen yang dilakukan terhadap kategori kemiripan produk dan pesan iklan. Eksperimen pada kedua studi tersebut dilakukan dengan menggunakan metode between-subject pada 240 mahasiswa tahap sarjana di Fakultas Ekonomi dan Bisnis, Universitas Airlangga (120 mahasiswa untuk masing-masing studi) sebagai partisipan. Hasil eksperimen dari studi pertama menunjukkan bahwa konsep merek bergengsi memiliki kemampuan yang lebih baik (dibandingkan dengan konsep merek fungsional) untuk melakukan perluasan merek baik pada kategori produk yang mirip maupun yang tidak mirip dengan merek asal. Studi kedua kemudian dilakukan dengan menggunakan merek bergengsi sebagai objek yang dijadikan rujukan. Hasil eksperimen dari studi tahap kedua menunjukkan bahwa merek bergengsi akan dapat meningkatkan kemampuannya dalam melakukan perluasan merek jika produk diiklankan dengan pesan social-adjustive untuk kategori produk yang mirip, dan untuk kategori produk yang tidak mirip akan lebih efektif jika diiklankan dengan pesan value-expressive.
\end{abstract}

\title{
INTRODUCTION
}

Perluasan merek (brand extension) merupakan penggunaan nama merek yang telah mapan atau merek yang terkenal untuk memperkenalkan produk baru (Keller, 2008; Hem dan Iversen, 2009). Strategi perluasan merek banyak digunakan perusahaan untuk meningkatkan ekuitas merek, memenuhi permintaan pasar yang baru serta memberikan keuntungan kompetitif yang baru (Monga dan John, 2010; Elliot, Percy, dan Pervan, 2011). Banyak perusahan yang mengalami kesuksesan ketika menggunakan strategi perluasan merek, seperti yang terjadi pada Samsung. Samsung menciptakan aneka produk untuk mereknya, seperti smartphone, tablet, kamera, perangkat rumah tangga dan komputer (Marketeers, 2012) dan menuai kesuksesan pada berbagai perluasan merek yang dilakukan. Hal ini dapat diketahui ketika Samsung menguasai pasar Tablet PC di Indonesia (Detik, 2012) serta berhasil menguasai pasar smartphone dengan mengalahkan Apple dan Nokia (Kompas, 2012).

Pada kenyataannya, tidak semua perusahaan berhasil dalam mengimplementasikan strategi perluasan merek. Batra, Lenk, dan Wedel (2010) mengungkapkan bahwa mayoritas perluasan merek yang dilaporkan gagal, 

menunjukkan perlu adanya metodologi yang memungkinkan untuk memprediksi strategi yang lebih baik terhadap kategori produk perluasan. Terdapat faktor yang menentukan sukses atau gagalnya perluasan merek yang dilakukan oleh perusahaan. Umumnya tingkat kemiripan atau kesesuaian antara kategori produk pada merek asal dan kategori produk perluasan menjadi indikasi dari penerimaan target pasar terhadap perluasan merek yang dilakukan perusahaan (Martinez dan Pina, 2003). Hem dan Iversen (2009) mengungkapkan bahwa perluasan merek yang paling sukses adalah perluasan yang memiliki kemiripan yang tinggi antara kategori produk merek asal (parent brand) dan produk perluasan. Seperti yang dilakukan oleh Sony. Dengan kategori produk merek asal yaitu televisi, Sony melakukan perluasan merek pada produk play stations, tape recorder, radio, dan laptop. Menurut Park, Milberg, dan Lawson (1991), kemiripan kategori produk dapat dilihat dari beberapa aspek yaitu kemiripan karakteristik produk, penggunaan produk, dan fungsi produk antara produk merek asal dan produk perluasan. Bagi perusahaan, tingkat kemiripan antara ketegori produk perluasan dengan produk pada merek asal dianggap paling penting ketika konsumen melakukan evaluasi terhadap perluasan merek (Thamaraiselvan dan Raja, 2008).

Konsumen cenderung untuk menilai kemiripan antara produk perluasan dan produk pada merek asal ketika melakukan evaluasi perluasan baru (Chang, dkk, 2011). Konsumen lebih memilih perluasan merek dengan kategori produk yang mirip (similar) dengan pada produk pada merek asal karena reputasi merek secara otomatis dapat dengan mudah disamaratakan pada produk perluasan (Chang, dkk, 2011). Sebaliknya, evaluasi konsumen terhadap perluasan merek akan tidak positif ketika kategori produk perluasan yang dilakukan oleh perusahaan tidak mirip (dissimilar) dari kategori produk pada merek asal. Hal ini dikarenakan asosiasi yang lebih menyebar (Martinez dan Pina, 2003). Namun dampak dari kemiripan kategori produk (mirip atau tidak mirip) dalam mempengaruhi konsumen dapat berbeda apabila perluasan merek dilakukan pada merek yang memiliki konsep yang berbeda. Park, Milberg, dan Lawson (1991) mengungkapkan bahwa setiap merek memiliki konsep yang berbeda. Konsep tersebut yaitu konsep merek bergengsi (simbolik) dan konsep merek fungsional. Konsep merek bergengsi adalah merek yang dirancang untuk menghubungkan individu dengan kelompok yang diinginkan, peran, atau citra diri (Park, Jaworski, dan MacInnis, 1986) seperti contoh Mercedes- Benz. Pada merek dengan konsep bergengsi, kemiripan kategori produk baik mirip ataupun tidak mirip dengan kategori produk pada merek asal akan mendapatkan respon yang positif dari konsumen (Park, Milberg, dan Lawson, 1991). Hal ini dikarenakan merek bergengsi memiliki konsep yang lebih abstrak sehingga konsumen dapat lebih menerima ketika konsep merek ini memperluas merek baik pada kategori produk yang mirip maupun yang tidak mirip (Monga dan John, 2010).

Sedangkan konsep merek fungsional didefinisikan sebagai merek dengan konsep fungsional yang dirancang untuk memenuhi kebutuhan konsumen (utilitarian) (Park, Jaworski, dan Maclnnis 1986) seperti contoh Toyota. Respon konsumen This is an open access article under the CC BY SA license (https://creativecommons.org/licenses/by-sa/4.0/) 
terhadap perluasan merek yang dilakukan pada konsep merek ini, tidak sebaik pada merek bergengsi baik untuk kategori produk yang mirip maupun yang tidak mirip (Park, Milberg, dan Lawson, 1991). Hal ini dikarenakan ketika dilakukan pada kategori produk yang mirip maupun tidak mirip, konsumen kesulitan untuk menghubungkan produk perluasan dengan produk pada merek asal ketika produk perluasan tersebut tidak memberikan fungsi yang sama (Monga dan John, 2010). Berbeda dengan yang dikemukakan oleh Park, Milberg dan Lawson (1991), hasil yang ditunjukkan dalam penelitian yang dilakukan oleh Lye, Venkateswarlu, dan Barrett (2001) menunjukkan bahwa konsep merek fungsional lebih memiliki kemampuan untuk memperluas merek dibandingkan dengan konsep merek bergengsi. Perbedaan ini membutuhkan penelitian lebih lanjut untuk mengetahui bagaimana respon konsumen terhadap perluasan merek yang dilakukan pada konsep merek yang berbeda dan dengan kemiripan kategori produk pada merek asal dan pada produk perluasan.

Beberapa penelitian yang menyebutkan bahwa merek bergengsi memiliki keuntungan ketika melakukan perluasan merek pada berbagai kategori produk, mengindikasikan bahwa merek bergengsi memiliki keuntungan bagi perusahaan. Selain itu, merek bergengsi juga berpotensi mencapai kesuksesan dan merupakan strategi yang menguntungkan (Riley, Lomax, dan Blunden, 2004). Adapun strategi pemasaran untuk konsep merek bergengsi harus berfokus pada komponen simbolik daripada komponen fungsional (Riley, Lomax, dan Blunden, 2004). Salah satu strategi pemasaran yang dapat dilakukan perusahaan adalah pada aktifitas promosi yaitu iklan. Iklan memainkan peran yang sangat penting untuk membangun citra merek mewah (bergengsi) dan mengkomunikasikan arti sosial atau budaya (Wilcox, Kim, dan Sen, 2009). Penelitian yang dilakukan oleh Wilcox, Kim, dan Sen (2009) menunjukkan bahwa pada merek yang mewah (bergengsi), iklan yang menyiratkan pesan dengan tujuan sosial yang berbeda akan memiliki respon yang berbeda dari konsumen.

Ketika melihat suatu pesan iklan, konsumen akan cenderung untuk memberikan respon yang lebih baik pada iklan yang sesuai dengan fungsi sikap yang dimiliki oleh masing-masing konsumen (Wilcox, Kim, dan Sen, 2009). Iklan yang menggunakan fungsi social-adjustive umumnya menyiratkan pesan tentang tujuan sosial seseorang. Sedangkan iklan yang menggunakan fungsi value- expressive umumnya menyiratkan pesan tentang nilai dan keyakinan diri konsumen (Wilcox, Kim, dan Sen, 2009). Sehingga ketika perluasan merek dilakukan pada kategori produk yang mirip maupun yang tidak mirip dengan pada merek asal dan diberi pesan iklan yang berbeda (menyesuaikan sosial/social-adjustive dan mengekspresikan nilai/value-expressive), maka konsumen akan mengevaluasi perluasan merek tersebut dengan berbeda. Konsumen akan lebih menerima perluasan merek yang diiklan dengan pesan social-adjustive karena pesan social-adjustive memiliki kaitan yang erat dengan gaya hidup dan memiliki konotasi 
status merek sehingga dapat mendorong orang untuk mengkonsumsi produk dibandingkan dengan iklan yang menggunakan pesan value- expressive (Wilcox, Kim, dan Sen, 2009).

Dengan paparan diatas, dapat diketahui bahwa kemiripan kategori produk, konsep merek, dan pesan iklan memiliki peran penting dalam kesuksesan perluasan merek. Mengingat ketiga variabel tersebut penting dalam perluasan merek serta masih jarang penelitian yang menguji secara bertahap ketiga variabel tersebut, maka dilakukannya penelitian ini dengan menggunakan pendekatan dua studi. Studi pertama dilakukan untuk mengetahui bagaimana pengaruh kemiripan kategori produk dan konsep merek dalam perluasan merek. Dimana konsep merek yang memiliki kemampuan lebih tinggi dalam memperluas merek baik pada kategori produk yang mirip maupun tidak mirip akan menjadi objek dalam studi kedua. Studi kedua dilakukan untuk memaksimalkan keuntungan yang dimiliki oleh konsep merek yang dapat memperluas merek pada berbagai kategori produk tersebut, dengan menghubungkannya dengan iklan yang menampilkan pesan yang sesuai dengan fungsi sikap masing-masing konsumen dan melihat pengaruhnya terhadap evaluasi perluasan merek oleh konsumen. LITERATURE

\section{REVIEW}

\section{The traditional society}

Perluasan merek terjadi ketika perusahaan menggunakan nama merek yang telah mapan atau merek yang terkenal untuk memperkenalkan produk baru (Keller, 2008; Hem dan Iversen, 2009). Perluasan merek biasanya mengunakan nama merek yang telah ada pada kategori lain dari produk, jasa atau industri yang baru (Batra, Lenk, dan Wedel, 2010; Temporal, 2010). Perluasan merek dapat dilakukan dengan menggunakan nama merek tunggal, kelompok merek, atau merek perusahaan (Elliot, Percy, dan Pervan, 2011). Perluasan merek merupakan penggunaan nama merek pada satu kelas produk untuk memasuki kelas produk lainnya (Aarker, 1991). Perluasan merek merupakan bentuk peningkatan manfaat dari familiarity pembeli dengan nama merek yang sudah ada pada suatu kelas produk untuk memperkenalkan lini produk baru pada kelas produk lainnya (Cravens dan Piercy, 2009).

\section{Previous Study and Hypothesis - Heading 2 (Calibri, 12, Bold, Capitalize Each Word)}

Konsumen lebih memilih perluasan dengan kategori produk yang serupa dengan merek asal, karena reputasi merek secara otomatis dapat dengan mudah disamaratakan dengan perluasan baru yang termasuk dalam kategori produk yang serupa (Chang, dkk, 2011). Sebaliknya, perluasan yang memiliki kategori produk yang jauh atau tidak mirip dengan merek asal akan mengakibatkan asosiasi (hubungan) yang lebih menyebar dan melemahkan reputasi dari merek asal (Chang, dkk, 2011).

$H_{1 \& 4}$ : Konsumen akan memiliki evaluasi yang lebih baik ketika perluasan merek dilakukan pada kategori produk yang mirip dengan merek asal dibandingkan pada

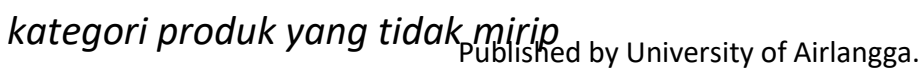

This is an open access article under the CC BY SA license (https://creativecommons.org/licenses/by-sa/4.0/) 
Isyarat kualitas dan isyarat manfaat sosial merek bergengsi akan memiliki sinyal pada konsumen bahwa dengan membeli merek bergengsi akan mengurangi resiko kinerja, resiko psikoliogis, dan resiko sosial yang secara normal berkaitan dengan keputusan pembelian produk (Baek, Kim, dan Yu, 2010). Dan konsumen memilih merek bergengsi terutama karena masalah kualitas dan faktor lain seperti membeli untuk mengesankan orang lain (Tsai, 2005). Sebaliknya, merek fungsional tidak memiliki positioning sebagai merek high end bagi konsumen (Temporal, 2010) dan memiliki keterkaitan dengan atribut tertentu serta kategori produk (Monga dan John, 2010).

$\mathrm{H}_{2}$ : Konsumen akan memiliki evaluasi yang lebih baik ketika perluasan merek dilakukan pada merek bergengsi dibandingkan pada merek fungsional

Ketika perluasan merek dilakukan pada kategori produk yang mirip persepsi konsumen tentang isyarat kualitas akan tetap berpindah pada produk perluasan tersebut sehingga akan mendapatkan tanggapan yang positif oleh konsumen. Sedangkan merek fungsional memiliki keterkaitan dengan atribut tertentu. Sehingga konsumen kesulitan untuk menghubungkan atau mencocokkan perluasan merek ketika kategori produk dari perluasan merek tersebut tidak memberikan fungsi yang sama dengan merek asal (Monga dan John, 2010).

Sama halnya untuk perluasan merek yang dilakukan pada kategori produk yang tidak mirip. Merek bergengsi memiliki memiliki nama merek yang mungkin tersimpan dalam ingatan konsumen sebagai merek yang memiliki kategori konsep mewah dan status. Sehingga ketika merek bergengsi meluncurkan produk yang tidak mirip, konsumen dengan mudah mengidentifikasi hubungan antara nama merek dengan konsep mewah dan status. Sehingga lebih dapat diterima dengan baik oleh konsumen (Park, Milberg, dan Lawson, 1991). Sedangkan untuk merek fungsional, merek fungsional memiliki nama merek yang mungkin tersimpan dalam ingatan konsumen sebagai merek yang memiliki kategori kelompok produk (product-class). Sehingga ketika merek fungsional meluncurkan produk yang tidak mirip, maka konsumen tidak mampu menghubungkan kaitan antara nama merek dengan konsep merek yang dimiliki (Park, Milberg, dan Lawson, 1991).

$H_{3}$ : Pada kategori produk yang mirip, konsumen akan memiliki evaluasi yang lebih baik ketika perluasan merek dilakukan pada merek bergengsi dibanding dengan merek fungsional. Pada kategori produk yang tidak mirip, konsumen akan memiliki evaluasi yang lebih baik ketika perluasan merek dilakukan pada merek bergengsi dibanding dengan merek fungsional

Fungsi sosial dari sikap telah terbukti mendasari berbagai tanggapan konsumen termasuk evaluasi produk (Shavitt, Lowrey, and Han, 1992). Konsumen dengan perbedaan pola pikir identitas sosial mempertimbangkan pentingnya merek ketika mengevaluasi produk simbolik dan produk non simbolik secara berbeda (Lee dan Shavit, 
2006). Czellar (2003) mengungkapkan bahwa perluasan merek tergantung pada gaya self-monitoring konsumen. Penelitian empiris menunjukkan bahwa individual dengan self-monitoring yang tinggi (fungsi social-adjustive) merespon dengan lebih baik pada iklan yang berorientasi pada pada status (Czellar, 2003) dan memilih merek yang sesuai dengan situasi sosial (Hog, Cox, dan Keeling, 2000). Sedangkan individu dengan selfmonitoring yang rendah (fungsi value-expressive) merespon dengan lebih baik pada iklan yang berdasar pada nilai dan prinsip dan memilih merek yang sesuai dengan kepribadian yang dimiliki (Wilcox, Kim, dan Sen, 2009). Dan iklan dengan pesan social-adjustive memiliki kaitan yang erat dengan gaya hidup dan memiliki konotasi status merek sehingga dapat mendorong orang untuk mengkonsumsi produk dibandingkan dengan iklan yang menggunakan pesan value- expressive (Wilcox, Kim, dan Sen, 2009).

$H_{5}$ : Konsumen akan memiliki evaluasi yang lebih baik ketika perluasan merek diiklankan dengan menggunakan pesan social-adjustive dibandingkan pesan value-expressive

Perluasan merek yang dilakukan pada kategori produk yang mirip, akan memiliki evaluasi yang lebih baik dari konsumen ketika produk diiklankan dengan menggunakan pesan social-adjustive dibandingkan dengan menggunakan pesan valueexpressive. Hal ini dikarenakan iklan dengan pesan social- adjustive memiliki kaitan yang erat dengan gaya hidup dan memiliki konotasi status merek sehingga dapat mendorong orang untuk mengkonsumsi produk dibandingkan dengan iklan yang menggunakan pesan value- expressive (Wilcox, Kim, dan Sen, 2009). Sama halnya dengan kategori produk yang mirip, perluasan merek pada kategori produk yang tidak mirip memiliki evaluasi yang lebih baik ketika diiklankan dengan menggunakan pesan social-adjustive dibandingkan dengan menggunakan pesan value-expressive. Karena iklan dengan pesan social-adjustive memiliki kaitan yang erat dengan gaya hidup dan memiliki konotasi status merek sehingga dapat mendorong orang untuk mengkonsumsi produk dibandingkan dengan iklan yang menggunakan pesan valueexpressive (Wilcox, Kim, dan Sen, 2009). Selain itu, menurut Rio, Vazquez, dan Iglesias (2001) konsumen akan mengevaluasi perluasan merek dengan lebih baik ketika produk dapat menaikkan reputasi konsumen di lingkungan sosial sehingga konsumen akan lebih dapat menerima perluasan merek pada berbagai kategori produk.

$H_{6}$ : Pada kategori produk yang mirip, konsumen akan memiliki evaluasi yang lebih baik ketika diiklankan dengan pesan social-adjustive dibandingkan pesan value-expressive. Pada kategori produk yang tidak mirip, konsumen akan memiliki evaluasi yang lebih baik ketika diiklankan dengan pesan social- adjustive dibandingkan pesan value- expressive. 


\section{RESEARCH METHODS}

Pengumpulan data dilakukan dalam beberapa tahap, yaitu studi pre-eliminary, cek manipulasi, pretest, dan main test. Populasi dalam penelitian ini adalah seluruh mahasiwa Strata 1 di Surabaya. Sedangkan sampel dalam penelitian ini adalah mahasiswa Strata 1 Fakultas Ekonomi dan Bisnis Universitas Airlangga Surabaya. Jumlah sampel yang digunakan adalah sebanyak 240 orang. Penelitian ini dilakukan dengan pendekatan dua studi secara bertahap. Studi pertama untuk mengetahui pengaruh kategori kemiripan (mirip dan tidak mirip) dan konsep merek (fungsional dan bergengsi) terhadap evaluasi perluasan merek oleh konsumen. Dengan variabel control yaitu regulatory focus. Sedangkan studi kedua untuk mengetahui pengaruh kategori kategori kemiripan (mirip dan tidak mirip) dan pesan iklan (social-adjustive dan value-expressive) terhadap evaluasi perluasan merek oleh konsumen juga dengan regulatory focus sebagai variabel control.

\section{RESULT AND ANALYSIS}

Tabel 1

Analisis Faktor, Uji Validitas, dan Uji Reliabilitas

\section{STUDI 1}

\begin{tabular}{|c|c|c|c|c|c|c|}
\hline Kode & Pertanyaan & $\begin{array}{c}\text { Factor } \\
\text { Loading }\end{array}$ & $\begin{array}{c}\text { Eigen- } \\
\text { value }\end{array}$ & $\begin{array}{c}\% \text { of } \\
\text { Variance }\end{array}$ & $\begin{array}{l}\text { Item-total } \\
\text { correlation }\end{array}$ & $\begin{array}{c}\text { Cronbach } \\
\text { Alpha }\end{array}$ \\
\hline \multicolumn{7}{|c|}{ Evaluasi Perluasan Merek (Monga dan John, 2010) } \\
\hline EV1 & Tidak sesuai/sesuai & 0,976 & 2,793 & 93,088 & 0.944 & 0.963 \\
\hline EV2 & Tidak konsisten/konsisten & 0,967 & & & 0.926 & \\
\hline EV3 & Buruk/baik & 0,951 & & & 0.893 & \\
\hline \multicolumn{7}{|c|}{ Regulatory Focus (Haws, Dholakia, dan Bearden, 2010) } \\
\hline RF1 & $\begin{array}{l}\text { Ketika saya melihat peluang } \\
\text { untuk sesuatu yang saya suka, } \\
\text { saya langsung } \\
\text { merasa bersemangat }\end{array}$ & 0,817 & 1,993 & 66,423 & 0.575 & 0.745 \\
\hline RF2 & $\begin{array}{l}\text { Saya sering membayangkan } \\
\text { bagaimana saya akan mencapai } \\
\text { harapan dan } \\
\text { aspirasi }\end{array}$ & 0,827 & & & 0.589 & \\
\hline RF3 & $\begin{array}{l}\text { Saya memandang diri saya } \\
\text { sebagai seseorang yang berusaha } \\
\text { untuk mencapai diri yang ideal } \\
\text { (ideal self) untuk memenuhi } \\
\text { harapan, } \\
\text { keinginan, dan aspirasi saya }\end{array}$ & 0,800 & & & 0.554 & \\
\hline
\end{tabular}


Arini Ekaputri Junaedi

\begin{tabular}{|c|c|c|c|c|c|c|}
\hline Kode & Pertanyaan & $\begin{array}{c}\text { Factor } \\
\text { Loading }\end{array}$ & $\begin{array}{l}\text { Eigen- } \\
\text { value }\end{array}$ & $\begin{array}{c}\% \text { of } \\
\text { Variance }\end{array}$ & $\begin{array}{l}\text { Item-total } \\
\text { correlation }\end{array}$ & $\begin{array}{c}\text { Cronbach } \\
\text { Alpha }\end{array}$ \\
\hline \multicolumn{7}{|c|}{ Evaluasi Perluasan Merek (Monga dan John, 2010) } \\
\hline EV1 & Tidak sesuai/sesuai & 0,962 & 2,698 & 89,917 & 0.913 & 0.944 \\
\hline EV2 & Tidak konsisten/konsisten & 0,940 & & & 0.866 & \\
\hline EV3 & Buruk/baik & 0,942 & & & 0.872 & \\
\hline \multicolumn{7}{|c|}{ Regulatory Focus (Haws, Dholakia, dan Bearden, 2010) } \\
\hline RF1 & $\begin{array}{l}\text { Ketika saya melihat peluang } \\
\text { untuk sesuatu yang saya suka, } \\
\text { saya langsung } \\
\text { merasa bersemangat }\end{array}$ & 0,770 & 1,902 & 63,403 & 0.491 & 0.703 \\
\hline RF2 & $\begin{array}{l}\text { Saya sering membayangkan } \\
\text { bagaimana saya akan mencapai } \\
\text { harapan dan } \\
\text { aspirasi }\end{array}$ & 0,830 & & & 0.577 & \\
\hline RF3 & $\begin{array}{l}\text { Saya memandang diri saya } \\
\text { sebagai seseorang yang } \\
\text { berusaha untuk mencapai diri } \\
\text { yang ideal (ideal self) untuk } \\
\text { memenuhi harapan, keinginan, } \\
\text { dan aspirasi saya }\end{array}$ & 0,788 & & & 0.509 & \\
\hline
\end{tabular}

Sumber: Data Diolah

Tabel 2

Uji ANCOVA

\begin{tabular}{|c|c|c|c|c|c|c|}
\hline \multirow{3}{*}{ Variabel } & \multicolumn{6}{|c|}{ Evaluasi Perluasan Merek } \\
\hline & \multicolumn{3}{|c|}{ Studi 1} & \multicolumn{3}{|c|}{ Studi 2} \\
\hline & Mean & F-value & Sig & Mean & F-value & Sig \\
\hline \multicolumn{7}{|c|}{ Main effect } \\
\hline \multicolumn{7}{|l|}{ Kemiripan } \\
\hline Mirip & 4,086 & 7,447 & 0,007 & 4,576 & 7,073 & 0,009 \\
\hline Tidak Mirip & 3,298 & & & 3,879 & & \\
\hline \multicolumn{7}{|l|}{ Konsep Merek } \\
\hline Bergengsi & 4,110 & 8,252 & 0,005 & 4,182 & 0,028 & 0,867 \\
\hline Fungsional & 3,274 & & & 4,223 & & \\
\hline \multicolumn{7}{|c|}{ Interaction effect } \\
\hline Mirip, bergengsi & 4,862 & \multirow{3}{*}{6,187} & \multirow{3}{*}{0,014} & 4,775 & \multirow{4}{*}{4,636} & \multirow{4}{*}{0,030} \\
\hline Mirip, fungsional & 3,310 & & & 4,279 & & \\
\hline Tidak mirip, bergengsi & 3,358 & & & 3,590 & & \\
\hline Tidak mirip, fungsional & 3,237 & & & 4,167 & & \\
\hline \multicolumn{7}{|c|}{ Co-variates } \\
\hline Regulatory Focus & & 0,036 & 0,849 & & 0,008 & 0,924 \\
\hline \multicolumn{7}{|c|}{ Sumber: Data Diolah } \\
\hline \multicolumn{7}{|c|}{$\begin{array}{l}\text { Hasil pengujian hipotesis } 1 \text { menyebutkan bahwa konsumen akan memiliki } \\
\text { evaluasi yang lebih baik ketika perluasan merek dilakukan pada kategori produk yang } \\
\text { mirip dengan merek asal dibandingkan pada kategori produk yang tidak mirip. Hal ini } \\
\text { Published by University of Airlangga. }\end{array}$} \\
\hline
\end{tabular}


sesuai dengan penelitian yang dilakukan oleh Chang, dkk (2011) yang mengungkapkan bahwa konsumen lebih memilih perluasan dengan kategori produk yang serupa dengan merek asal, karena reputasi merek secara otomatis dapat dengan mudah disamaratakan dengan perluasan baru yang termasuk dalam kategori produk yang serupa. Dan pada perluasan merek yang memiliki kategori produk yang jauh atau tidak mirip dengan merek asal akan mengakibatkan asosiasi (hubungan) yang lebih menyebar dan melemahkan reputasi dari merek asal. Sehingga konsumen lebih memilih perluasan yang dilakukan dengan kategori produk yang mirip dibandingkan dengan yang tidak mirip. Dengan demikian hipotesis pertama ini juga sesuai dengan penelitian yang dilakukan Shen, Bei, dan Chu (2011) yang menyatakan bahwa evaluasi perluasan merek oleh konsumen ditentukan oleh kemiripan antara kategori produk inti dengan kategori produk esktensi.

Hasil pengujian hipotesis 2 menyebutkan bahwa konsumen akan memiliki evaluasi yang lebih baik ketika perluasan merek dilakukan pada merek bergengsi dibandingkan pada merek fungsional. Hasil pengujian hipotesis kedua ini sesuai dengan penelitian yang dilakukan oleh Park, Milberg, dan Lawson (1991) serta Monga dan John (2010). Hal ini disebabkan karena isyarat kualitas dan isyarat manfaat sosial merek bergengsi akan memiliki sinyal pada konsumen bahwa dengan membeli merek bergengsi akan mengurangi resiko kinerja, resiko psikoliogis, dan resiko sosial yang secara normal berkaitan dengan keputusan pembelian produk (Baek, Kim, dan Yu, 2010). Dan merek fungsional tidak memiliki positioning sebagai merek high end bagi konsumen (Temporal, 2010) dan memiliki keterkaitan dengan atribut tertentu serta kategori produk (Monga dan John, 2010). Sehingga konsumen lebih menerima perluasan merek yang dilakukan pada merek bergengsi dibandingkan dengan merek fungsional.

Hasil pengujian hipotesis 3 menyebutkan bahwa pada kategori produk yang mirip, konsumen akan memiliki evaluasi yang lebih baik ketika perluasan merek dilakukan pada merek bergengsi dibanding merek fungsional. Hal ini sesuai dengan penelitian Park, Milberg, dan Lawson (1991), merek bergengsi memiliki isyarat kualitas dimana akan tetap berpindah pada produk perluasan yang dilakukan. Sehingga konsumen akan tetap memiliki evaluasi yang baik pada perluasan merek yang dilakukan pada merek bergengsi. Sedangkan merek fungsional memiliki keterkaitan dengan atribut tertentu sehingga ketika melakukan perluasan merek baik pada kategori produk yang mirip konsumen akan kesulitan menghubungkan fungsi antara produk merek asal dan produk perluasan merek (Monga dan John, 2010)

Hasil pengujian hipotesis 3 menyebutkan bahwa pada kategori produk yang tidak mirip, konsumen akan memiliki evaluasi yang lebih baik ketika perluasan merek dilakukan pada merek bergengsi dibanding merek fungsional. Hal ini sesuai dengan hasil penelitian dari Park, Milberg, dan Lawson (1991) yang menyebutkan bahwa 
merek bergengsi dapat diluncurkan dengan sukses ketika memperluas merek dengan jarak yang jauh karena konsumen dapat menggunakan konsep bergengsi untuk menghubungkan merek asal dengan perluasan merek. Ini juga dipertegas oleh Monga dan John (2010) yang mengungkapkan bahwa merek bergengsi memiliki konsep merek yang lebih abstrak dibandingkan dengan merek fungsional sehingga dapat berhasil ketika memperluas merek pada berbagai kategori produk. Dan karena konsumen kesulitan untuk menghubungkan atau mencocokkan merek asal dengan perluasan merek ketika perluasan merek diakukan pada merek fungsional maka konsumen akan merasakan memiliki resiko yang lebih besar (Chang, dkk, 2011)

Selain itu, hipotesis 3 menyebutkan bahwa merek bergengsi dapat dengan sukses memperluas merek baik pada kategori produk yang mirip maupun yang tidak mirip dibanding merek fungsional. Sehingga studi pertama yang dilakukan mendukung penelitian yang dilakukan oleh Park, Milberg, dan Lawson (1991) yang menyatakan konsumen lebih menerima perluasan merek yang dilakukan pada konsep merek bergengsi dibanding merek fungsional.

Pada studi 2, hasil pengujian hipotesis menyebutkan bahwa konsumen akan memiliki evaluasi yang lebih baik ketika perluasan merek dilakukan pada kategori produk yang mirip dengan merek asal dibandingkan pada kategori produk yang tidak mirip. Sama halnya dengan pada studi pertama, hasil hipotesis keempat ini sesuai dengan penelitian yang dilakukan Chen, dkk (2011) dan Shen, Bei, dan Chu (2011) dimana evaluasi perluasan merek oleh konsumen ditentukan oleh kemiripan antara kategori produk inti dengan kategori produk esktensi. Hal ini dikarenakan karena reputasi merek secara otomatis dapat dengan mudah disamaratakan dengan perluasan baru yang termasuk dalam kategori produk yang serupa. Dan pada kategori produk yang tidak mirip, resiko yang dirasakan oleh pembeli lebih besar karena pembeli yang potensial memiliki informasi yang sedikit untuk meramalkan performa dari perluasan yang dilakukan. Sehingga konsumen lebih menerima perluasan merek pada kategori produk yang mirip dibandingkan dengan tidak mirip dengan produk pada merek asal.

Hasil pengujian hipotesis 5 menyatakan bahwa tidak terdapat perbedaan antara perluasan merek yang diiklankan dengan pesan social-adjustive dan pesan valueexpressive. Hasil pengujian hipotesis kelima ini berbeda dengan yang diungkapkan oleh Wilcox, Kim, dan Sen (2009) yaitu iklan dengan pesan social-adjustive memiliki kaitan yang erat dengan gaya hidup dan memiliki konotasi status merek sehingga dapat mendorong orang untuk mengkonsumsi produk dibandingkan dengan iklan yang menggunakan pesan value-expressive (Wilcox, Kim, dan Sen, 2009). Hal ini dimungkinkan ketika konsumen melihat suatu iklan dengan fungsi sikap tertentu, sikap yang dimiliki konsumen memberikan fungsi baik fungsi social-adjustive maupun fungsi value- expressive secara bersamaan. Ini dikarena menurut Shavitt (1989), sikap konsumen terhadap merek mewah dapat memberikan fungi social-adjustive, fungsi value-expressive, atau kedelamshiad by University of Airlangga.

This is an open access article under the CC BY SA license (https://creativecommons.org/licenses/by-sa/4.0/) 
Hasil pengujian hipotesis 6 menyatakan bahwa pada kategori produk yang mirip, konsumen akan memiliki evaluasi yang lebih baik ketika perluasan merek diiklankan dengan pesan social-adjustive dibanding dengan pesan value-expressive. Sebagaimana yang telah disampaikan oleh Synder dan DeBono (1985) yang menyatakan bahwa konsumen merespon dengan lebih baik pada citra (image) atau daya tarik bentuk produk ketika menggunakan fungsi sikap social- adjustive. Menurut Rio, Vazquet, dan Iglesias (2001), konsumen akan mengevaluasi perluasan merek dengan lebih baik ketika dapat menaikkan reputasi konsumen. Sehingga konsumen akan bersedia menerima perluasan merek pada kategori produk lain.

Selain itu, hasil untuk hipotesis 6, kategori produk yang tidak mirip, konsumen akan memiliki evaluasi yang lebih baik ketika perluasan merek diiklankan dengan pesan value-expressive dibanding dengan pesan social-adjustive. Hal ini berbanding terbalik dengan Rio, Vazquet, dan Iglesias (2001), yang mengemukakan bahwa ketika perluasan merek dilakukan pada kategori lain, maka konsumen akan bersedia menerima selama memiliki citra (image) yang akan menaikkan reputasi ketika ketika perluasan merek diiklankan dengan pesan social-adjustive (Synder dan DeBono, 1985). Hal ini dimungkinkan karena produk yang digunakan adalah mobil dimana mobil memiliki citra untuk pengguna produk yang lebih tinggi dibandingkan dengan kacamata. Misalnya, mobil Rolex memiliki citra klasik,dan elegan maka pengguna mobil akan memiliki citra diri sesuai dengan mobil yang ditumpangi. Hal ini dikarenakan semakin tinggi kesesuaian antara diri sendiri dengan produk, maka akan meningkatkan kepuasan dari kebutuhan konsistensi diri sehingga dapat meningkatkan sikap terhadap suatu produk (Johar, dan Syrgy, 1991). Untuk variabel yang menjadi covariates yaitu regulatory focus, tidak memiliki pengaruh terhadap evaluasi perluasan merek oleh konsumen. Hal ini kontras dengan penelitian Yeo dan Park (2006); Shine, Park, dan Wyer (2007) dan Chang, dkk (2011). Ini dimungkinankan karena konsumen memiliki kedua jenis regulatory focus (promosi dan prevensi) sekaligus (Higgins, 2002).

\section{CONCLUSION}

Penelitian ini mengungkapkan bahwa terjadi hubungan antara kemiripan kategori produk perluasan dengan produk merek asal dengan konsep merek yang dimiliki oleh merek asal dalam evaluasi yang dilakukan oleh konsumen. Hal ini akan menambah informasi bagi akademisi akan pentingnya konsep merek dan kategori kemiripan dalam melakukan perluasan merek. Penelitian ini juga menjelaskan bagaimana suatu iklan yang menggunakan pesan tertentu (baik social-adjustive dan value-expressive) mempengaruhi penerimaan suatu perluasan merek yang dilakukan oleh suatu perusahaan. Sehingga hal tersebut menjadi perlu untuk menjadi tambahan pengetahuan dalam kaitan perluasan merek. 
Berdasarkan penelitian yang dilakukan dapat diketahui bahwa merek bergengsi memiliki kemampuan yang lebih tinggi dalam melakukan perluasan merek. Merek bergengsi dapat memperluas mereknya dari kategori produk yang mirip sampai dengan kategori produk yang tidak mirip. Sehingga perusahaan dapat mengambil keuntungan dengan adanya konsep merek bergengsi ini. Meskipun konsep/citra bergengsi lebih sulit dibangun pada suatu merek dibanding dengan konsep fungsional, tetapi dibalik itu terdapat keuntungan yang besar pada merek bergengsi ketika melakukan perluasan merek. Selain itu, berdasarkan penelitian yang dilakukan dapat diketahui bahwa merek bergengsi akan lebih memudahkan penerimaan oleh konsumen ketika melakukan perluasan merek yang diiklankan dengan pesan social-adjustive untuk kategori produk yang mirip. Namun perluasan merek yang diiklankan dengan pesan value-expressive akan lebih dapat diterima oleh konsumen ketika dilakukan pada kategori produk yang tidak mirip. Sehingga perusahaan yang melakukan perluasan merek pada kategori produk yang tidak mirip, disarankan untuk menggunakan iklan dengan pesan valueexpressive agar lebih efektif.

\section{REFERENCES}

Aarker, D.A. 1991. Managing Brand Equity. United States of America : Fress Press. , and Keller L.K. 1990. Consumer Evaluation of Brand Extension. Journal of Marketing. 54 (1) : 27-41.

Alden, D.L., Jan-Benedict E.M. Steenkamp, and R. Batra. 1999. Brand Positioning through Advertising in Asia, North America, and Europe: The Role of Global Consumer Culture. Journal of Marketing. $63: 75-87$

Baek, T., J. Kim, and J.H. Yu. 2010. The Differential Roles of Brand Credibility and Brand Prestige in Consumer Brand Choice. Phsychology and Marketing. 27 (7) : 662-678.

Batra, R., P. Lenk, and M. Wedel. 2010. Brand Extension Strategy Planning: Empirical Estimation of Brand- Category Personality Fit and Atypicality. Journal of Marketing Research. 47 (4) : 335-347

Bazzini, D.G., and D.R. Shaffer. 1995. Investigating the Social-Adjustive and ValueExpressive Functions of Well- Grounded Attitudes: Implications for Change and for Subsequent Behavior. Motivation and Emotion. 19 (4) : 279305.

Bhat, S., and S.K. Reddy. 1998. Symbolic and Functional Positioning of Brands. Journal of Consumer Marketing. 15 : 32-43.

Chang, C., B. Lin, and S. Chang. 2011. The Relative Advantages of Benefit Overlap versus Category Similarity in Brand Extension Evaluation : The Moderating Role of Self-Regulatory Focus. Marketing Letter. 22 : 391-404. 
Clow, K.E., and D. Baack. 2004. Integrated Advertising, Promotion, and Marketing Communication. 2nd Edition. New Jersey : Pearson.

Cravens, D.W., and N.F. Piercy. 2009. Strategic Marketing. 9th Edition. New York : McGraw-Hill.

Czellar, S. 2003. Consumer Attitude towards Brand Extensions: an Integrative Model and Research Propositions. International Journal of Research in Marketing. 20 : 97-115.

DeBono, K.G. 1987. Investigating the Social Adjustive and Value Expressive Functions of Attitudes: Implications for Persuasion Processes. Journal of Personality and Social Psychology. 52 (2) : 279-287.

Elliot, R., L. Percy, and S. Pervan. 2011. Strategic Brand Management. 2nd Edition. New York: Oxford University Press Inc.

Gierl, H., and V. Huettl. 2011. A Closer Look at Similarity: The Effects of Perceived Similarity and Conjunctives Cues on Brand Extension Evaluation. Intern. J. of Research in Marketing. 28 : 120-133.

Graeff, T.R. 1996. Using Promotional Message to Manage the Effects of Brand and Self-image on Brand Evaluation. Journal of Consumer Marketing. 13 : 4- 18.

Hair, J.F., W.C. Black, B.J. Babin, and R.E. Anderson. 2010. Multivariate Data Analysis : A Global Perspective. 7th Edition. United State of America : Pearson.

Haws, K.L., U.L. Dholakia, and W.O. Bearden. 2010. An Assessment of Chronic Regulatory Focus Measures. Journal of Marketing Research. 47 (10) : 967-982.

Hem, L.E., and N.M. Iversen. 2009. Effects of Different Types of Perceived Similarity and Subjective Knowledge in Evaluations of Brand Extensions. International Journal of Market Research. 51 : 797-818.

, L.D. Chernatony, and N.M. Iversen. 2003. Factors Influencing Successfull Brand Extensions. Journal of Marketing Management. 19: 781-806.

Heriyanto, T. 2012. Samsung : Kami Menguasai Pasar Tablet PC Indonesia. http://inet.detik.com. Diakses tanggal 20 Juni 2012.

Higgins, E.T. 2002. How Self-Regulation Creates Distint Values: The Case of Promotion and Prevention Decision Making, Journal of Consumer Psychology. 12 (3) : 177-191

Ghozali, I. 2009. Aplikasi Analisis _ _ 1997. Beyond Pleasure and Pain Multivariate dengan Program SPSS. Semarang : BP Undip. . 2006. Aplikasi Analisis Multivariate dengan Program SPSS. Semarang : BP Undip American Psychologist. 52 (12) : 1280-1300. 
Evaluation. European Journal of Marketing. 34 : 641 - 667

Johar, J.S., and M.J. Syrgy. 1991. Value- Expressiveversus Utilitarian Advertising Appeals : When and Why to Use Which Appeal. Journal of Advertising. 20 (9) : 2223.

Keller, K.L. 2008. Strategic Brand Management. 3rd Edition. United States of America : Prentice Hall.

, and D.A. Aarker. 1992. The Effect of Sequential Introduction of Brand Extension. Journal of Marketing Research. 29 (2) : 35-30.

Kim, H., and D.R. John. 2008.. Consumer Response to Brand Extensions : Construal Level as a Moderator of the Importance of Fit. Journal of Consumer Psychology. $18: 116-126$.

Kotler, P., and K.L. Keller. 2012. Marketing Management. 14th Edition. United States of America : Pearson.

Laforet, S. 2010. Managing Brand. New York : McGraw-Hill.

LeBouef, R.A., and J.P. Simmons. 2010. Branding Alters Attitude Functions and Reduces the Advantage of Function- Matching Persuasive Appeals. Journal of Marketing Research. 42 (11) : 348360.

Lee, K., and S. Shavitt. 2006. The Use of Cues Depends on Goals: Store Reputation Affects Product Judgments When Social Image Goals Are Salient. Journal of Consumer Psychology. 16 (3) : 260-71.

Lye, A., P. Venkateswarlu, and J. Barrett. 2001. Brand Extension : Prestige Brand Effects. Australasian Marketing Journal. 9 (2) : 53-65.

Martinez, E., and J.M. Pina. 2003. The Negative Impact of Brand Extension on Parent Brand Image. Journal of Product \& Brand Management. 12 (7) : 432-448.

Meyvis, T., K. Goldsmith, and R. Dhar. 2012. The Importance of the Context in Brand Extension : How Pictures and

Hogg, M.K., A.J.Cox, and K. Keeling. 2000. The Impact of Self-monitoring on Image Congruence and Product/Brand Comparisons Shift Consumers' Focus from Fit to Quality. Journal of Marketing Research. 49 (4) : 206 -217.

Monga, A.B., and D.R. John. 2010. What Makes Brands Elastic? The Influence of Brand Concept and Styles of Thinking on Brand Extension Evaluation. Journal of Marketing. 74 (5) : 80-92.

Park, C.W., S. Milberg, and R. Lawson. 1991. Evaluation of Brand Extension : The Role of Product Feature Similarity and Brand Concept Consistency. Journal of Consumer Research. 18 (9) : 185-193. 
B.J. Jaworski, and D.J. MacInnis. 1986. Strategic Brand Concept-Image Management. Journal of Marketing. 50(10) : 135-145.

Pham, M.T., and H.H. Chang. 2010. Regulatory Focus, Regulatory Fit, and the Search and Consideration of Choice Alternatives. Journal of Consumer Research. 37 (10) : 626-640.

Purwanto, D. 2012. Kalahkan Apple and Nokia, Samsung Jadi Raja Ponsel. http://tekno.kompas.com. Diakses tanggal 20 Juni 2012.

Riley, F.D., W. Lomax, and A. Blunden. 2004. Dove vs Dior: Extending the Brand Extension Decision-Making Process from Mass to Luxury. Australasian Marketing Journal. 12 (3) : 40-55.

Rio, A.B., R. Vazquez, and V. Iglesias. 2001. The Effect of Brand Associations on Consumer Response. Journal of Consumer Marketing. 18 : 410-425.

Santoso, S. 2010. Statistik Multivariate Konsep dan Aplikasi dengan SPSS. Jakarta : PT Elex Media Komputindo. . 2002. Buku Latihan SPSS: Statistik Parametrik. Cetakan Ketiga. Jakarta: PT. Elex Media Komputindo.

Shavitt, S., T. Lowrey, and S. Han. 1992. Attitude Function in Advertising : The Interactive Role of products and Self- Monitoring. Journal of Consumer Psychology. 1(4) : 337-364 . 1989. Products, Personalities and Situations in Attitude Functions: Implications for Consumer Behavior. Advanced in Consumer Research. 16 : 300-305.

Shen, T., L. Bei, and C. Chu. 2011. Consumer Evaluation Brand Extension : The Roles of Cased-Based Reminding on Brand-to- Brand Similarity. Psychology \& Marketing. 28 (1) : 91-113.

Shine, B.C., J. Park, and R.S. Wyer Jr. 2007. Brand Synergy Effects in Multiple Brand Extensions. Journal of Marketing Research. 44 (11) : 663-670.

Sigitkurniawan. 2012. Cara-cara Leveraging the Brand. http://the-marketeers.com. Diakses pada tanggal 20 Juni 2012.

Swanson, M. 2012. Rolex Is Most Popular Pentamillionaire Luxury Watch Brand. http://www.bloomberg.com. Diakses tanggal 20 Juni 2012.

Synder, M., and S. Gangstead. 1986. On the Nature odf Self-monitoring: Matters of Assessment, Matters of Validity", Journal of Personality and Social Psychology. 51 : 125-139.

and K.G. DeBono. 1985. Appeals to Image and Claims About Quality: Understanding the Psychology of Advertising. Journal of Personality and Social Psychology. 49 (3) : 586-97. 
. 1979. Self-monitoring Processes. Advances in Experimental Social Psychology. $30: 85-125$.

. 1974. Self-monitoring and Expressive Behavior. Journal of Personality and Social Psychology. 30 : 526-537.

Temporal, P. 2010. Advanced Brand Management. 2nd Edition. Singapore: John Willey \& Sons.

Thamaraiselvan, T., and J. Raja. 2008. How Do Consumers Evaluate Brand ExtensionsResearch Findings from India. Journal of Service Research. 8 : 43-62.

Tsai, S. 2005. Impact of Personal Orientation on Luxury-brand Purchase Value. International Journal of Market Research. 47 : 429-454.

Wilcox, K., H.M. Kim, and S. Sen. 2009. Why Do Consumer Buy Counterfeit Luxury Brands?. Journal of Marketing Research. 46 (4) : 247-259

Yamin, S., dan H. Kurniawan. 2009. Structural Equation Modeling. Jakarta : Salemba Infotek.

Yeo, J., and J. Park. 2006. Effect of Parent- Extension Similarity and Self Regulatory Focus on Evaluations of Brand Extensions. Journal of Consumer Psychology. 16 (3) : 272- 282.

Yeung, C.W.M., and R.S. Wyer Jr. 2005. Does Loving a Brand Mean Loving Its Products? The Role of Brand-Elicited Affect in Brand Extension Evaluations. Journal of Marketing Research. 42 (11) : 495-506.

Zhao, G., and C. Pechmann. 2007. The Impact of Regulatory Focus on Adolescents' Response to Antismoking Advertising Campaigns. Journal of Marketing Research. 44 (11) : 671-687.

Zhu, R., and M. Joan. 2007. Exploring the Cognitive Mechanism that Underlies Regulatory Focus Effects. Journal of Consumer Research. 34 (6) : 89-96. 